\title{
A large mantle water source for the northern San Andreas fault system: a ghost of subduction past
}

Stephen $\mathrm{H} \mathrm{Kirby}^{{ }^{*}}$, Kelin Wang ${ }^{2}$ and Thomas M Brocher ${ }^{1}$

\begin{abstract}
Recent research indicates that the shallow mantle of the Cascadia subduction margin under near-coastal Pacific Northwest, USA is cold and partially serpentinized, storing large quantities of water in this wedge-shaped region. Such a wedge probably formed to the south in California during an earlier period of subduction. We show by numerical modeling that after subduction ceased with the creation of the San Andreas Fault System (SAFS), the mantle wedge warmed, slowly releasing its water over a period of more than $25 \mathrm{Ma}$ by serpentine dehydration into the crust above. This deep, long-term water source could facilitate fault slip in San Andreas System at low shear stresses by raising pore pressures in a broad region above the wedge. Moreover, the location and breadth of the water release from this model gives insights into the position and breadth of the SAFS. Such a mantle source of water also likely plays a role in the occurrence of non-volcanic tremor (NVT) that has been reported along the SAFS in central California. This process of water release from mantle depths could also mobilize mantle serpentinite from the wedge above the dehydration front, permitting upward emplacement of serpentinite bodies by faulting or by diapiric ascent. Specimens of serpentinite collected from tectonically emplaced serpentinite blocks along the SAFS show mineralogical and structural evidence of high fluid pressures during ascent from depth. Serpentinite dehydration may also lead to tectonic mobility along other plate boundaries that succeed subduction, such as other continental transforms, collision zones, or along present-day subduction zones where spreading centers are subducting.
\end{abstract}

Keywords: Serpentinite; Antigorite; Lizardite; Chrysotile; Ophiolite; Mantle water; San Andreas Fault System; Subduction; California Coast Ranges; Non-volcanic tremor

\section{Background}

A deep, long-term mantle source of pressurized water has been hypothesized by others for the San Andreas Fault System (SAFS) to give insights into the spatial style and pattern of earthquake fault slip and in situ stress state (e.g., Irwin and Barnes 1975; Zoback et al. 1987; Zoback et al. 1993; Rice 1992; Hickman et al. 1995; Faulkner and Rutter 2001; Thomas et al. 2009) and into the geochemistry of groundwater along this system (Irwin and Barnes 1980; Kennedy et al. 1997; Kharaka et al. 1999). Prior to our work, the physical nature of this posited source had not been identified. Serpentinite and related rocks often occur as fault-emplaced blocks or diapiric bodies in near-coastal (Coast Range) California and their distribution broadly coincides with the region

\footnotetext{
*Correspondence: skirby@usgs.gov

'U.S. Geological Survey MS 977, 345 Middlefield Road, Menlo Park, CA 94025, USA

Full list of author information is available at the end of the article
}

of the SAFS. These rocks are thought to be of mantle origin, but it has been unclear by what process they are brought to the surface, since the most common serpentine mineral in such bodies in California, lizardite, itself is a rock with high coefficient of friction and a relatively high ductile strength at high effective pressures when deformed in the laboratory at elevated pressures and temperatures within its own stability field in the absence of excess free water (Raleigh and Paterson 1965; Moore et al. 1997; Hirth and Guillot 2013; Hilairet et al. 2007). Such vertical emplacement through the crust could also be facilitated by water pressure released by serpentine dehydration in the mantle (Raleigh and Paterson 1965) and possibly weakening effects associated with hydrothermal processes. These features of the SAFS and the occurrence of serpentinite could therefore be related.

A clue to the connection between SAFS tectonics and seismicity on the one hand and the distribution of serpentinite in California on the other comes from knowledge of 
the geologic history of California (Figures 1 and 2). The present-day continental margin of California south of the Mendocino Triple Junction (MTJ; Figure 1) was formerly the forearc of the Farallon : North America subduction system and presumably similar to the forearc of the adjacent present-day Cascadia subduction margin to the north (Atwater 1970; Atwater and Stock 1998; Wallace 1990). An investigation of the seismic-wave-speed structure of the western Oregon subduction margin in Cascadia by Bostock and others (2002) proposed that seismological survey data in Oregon are best explained if the forearc mantle in the southern Cascadia system is partially serpentinized, a condition caused by the release of water by Juan de Fuca (Gorda) slab dehydration below it. According to this model, the shallow part of forearc mantle nearest trenches should be cold enough to be within the stability field of antigorite (Peacock 1993; Bostock et al. 2002), an important serpentine mineral associated with peridotite alteration. The presence of partially serpentinized mantle nearest the trench reduces the wave-speed contrast with the crust above it, and, according to this model, mutes the expression of the Moho. A survey of seismological observations indicates a lack of clear continental Moho expression over much of the near-coastal active Cascadia subduction system and provides evidence for widespread serpentinization of the Cascadia forearc mantle (Brocher et al. 2003). A partially serpentinized forearc is also consistent with gravity and aeromagnetic anomalies in Oregon (Blakely et al. 2005) and also with the transition with increasing depth from interplate thrust earthquake slip to aseismic slip in some other subduction systems (Hyndman et al. 1997; Hyndman and Peacock 2003).

The northern California subduction margin began to transition to the SAFS with the northward migration of the MTJ beginning at about 25 to $30 \mathrm{Ma} \mathrm{BP}$ (Atwater and Stock 1998). This transition has important consequences for the fate of serpentinite in the forearc mantle of California that presumably had been formed during the subduction era. The serpentinized wedge forms and is stable because the colder slab keeps the forearc cool and because water is released from slabs by dehydration as they descend (Peacock 1993; Kirby 1995; Kirby et al. 1996). The degree of serpentinization is also expected to be significantly higher nearest the tip of the forearc mantle wedge (Wada et al. 2008). A recent unpublished tomographic study of the northern Cascadia region in Canada indicates that an average of $30 \%$ to $40 \%$ of the cold wedge is probably serpentinized (Roy Hyndman, personal communication), a figure somewhat lower than the Bostock et al. (2002) estimate of 50\% for Oregon. Reynard (2013) used relevant antigorite properties to estimate that up to $80 \%$ of the coldest Cascadia mantle forearc under Oregon may be serpentinized. The spatial extent of serpentinization in this wedge-shaped region depends not only on the pressure-temperature conditions in the wedge, but also on the details of transport of water released from the slab into the wedge, a process about which we are beginning to know more (Padrón-Navarta et al. 2010). Although a closely accurate estimate of the level of serpentinization is difficult to determine from geophysical observations alone, the amount of serpentine in the wedge based on the above estimates is large enough to produce the observed seismic and geophysical anomalies, and the potential amount of water stored in and later released from such a serpentinized wedge is enormous, as addressed in this study.

As we shall show, after subduction ceases, both the slab and the forearc warm up as heat flows from the deeper mantle, serpentine in the wedge becomes thermally unstable, and the wedge-shaped serpentinized mantle forearc region should shrink, releasing water into the near-coastal crust of the former forearc. This model, reported in conference abstracts earlier (Kirby et al. 2002, 2003), also gives insights into important aspects of the geology, earthquake physics, and tectonics of the continental margin of California, as discussed later in this paper.

An earlier unpublished version of this paper served as the conceptual basis, and some of the quantitative assumptions in fluid transport modeling by Fulton and Saffer (2009). They showed, using realistic fluid transport properties of the crust, that the fluid discharge rates from our model are sufficient to produce high fluid pressures in the seismogenic zone of the SAFS that approach lithostatic pressures. Becken et al. (2011) show that electrical resistivity surveys measured across the SAF near Parkfield, California are consistent with vertical zones of low resistivity. Citing the Fulton and Saffer paper, Becken et al. (2011) interpret these zones as representing fluid pathways where high-pressure fluids reduce resistance to frictional sliding. The present paper documents the modeling results that are, at least in part, the basis of interpretations in these later studies, and, in particular, the present paper documents the conceptual and numerical formulation of the model, and the rates of fluid discharge and the longevity of this source of pressurized water from our modeling results. Moreover, we suggest that this posited source of water from the mantle gives additional insight into the occurrence of non-volcanic tremor reported to occur along the San Andreas Fault in central California. Lastly, we suggest that the spatial distribution of some serpentinite bodies in the Coast Ranges of California may owe their existence to the mobility of mantle-derived ultramafic rocks (both partially serpentinized peridotites and their host serpentinites) conferred by the high fluid pressures that accompany this process. 


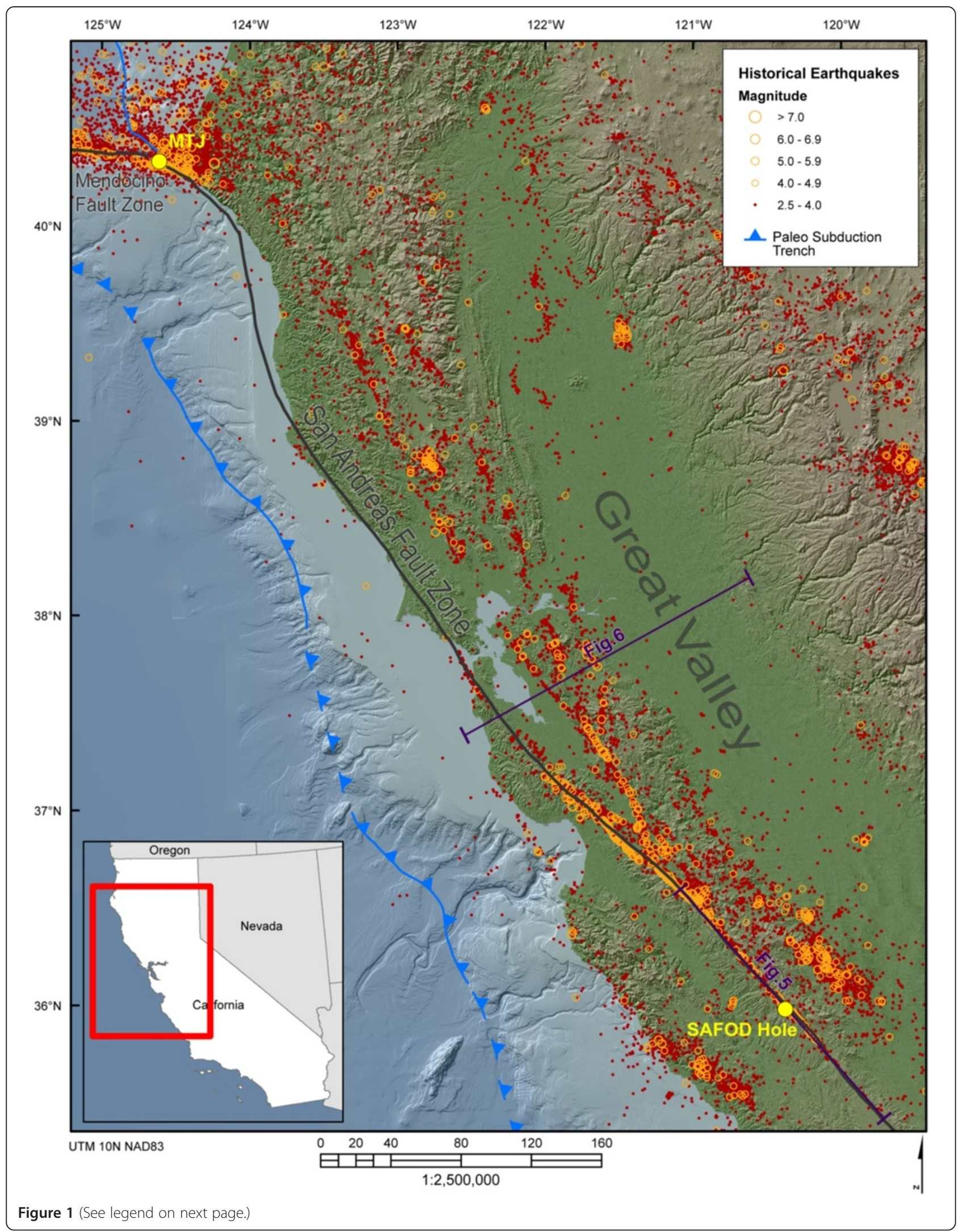


(See figure on previous page.)

Figure 1 Seismological and geological settings of San Andreas Fault System (SAFS) in northern California. Color-shaded relief map and seismicity of the California margin from just north of Mendocino Triple Junction (MTJ) to the latitude of just south of Parkfield. Seismicity from 1967 to 2010 from the Northern California Earthquake Data Center (NCEDC 2012) shown as red dots for events smaller than M4 and orange open circles for larger events. A simplified trace of the main San Andreas Fault sensu strictu (SAFss) is shown. The seismicity itself marks the approximate locations of most of the other members of the seismologically active San Andreas Fault System between the Great Valley and the SAFss and active strands to the east and west of it. The fossil trench of the former Farallon : North America subduction system is taken from McCulloch (1987), dashed where interpolated. The strike-parallel and strike-normal purple lines represent the locations of geophysical cross sections corresponding to Figure 6 and Figure 7, respectively.

\section{Methods}

\section{Model approach and assumptions}

During its long Mesozoic and early Tertiary subduction history, the continental margin of California acquired a complex petrologic and tectonic structure that was later overprinted by the tectonics of the San Andreas transform plate boundary zone and the related Coast Range tectonics. The Cascadia subduction system north of the Mendocino triple junction (MTJ), having a presumably comparable history of subduction and terrane accretion as earlier in California, is probably our best present-day analogue to the subduction-zone era of the California margin. We carried out thermo-mineralogical modeling of the post-subduction fossil forearc using a twodimensional finite element model. Except for an iterative approach to deal with a moving metamorphic boundary with the evolving thermal field and the associated latent heat, the modeling method is the same as described in Wang et al. (1995) and Peacock and Wang (1999). We first developed a steady-state subduction model. Using temperatures from this steady-state model as the initial condition, we proceeded with modeling the warming history of the margin after the cessation of subduction.

\section{Starting subduction model}

Our starting steady-state thermo-mineralogical model of subduction is essentially the same as that adopted by Bostock and others (2002) for the Cascadia subduction margin in Oregon and broadly consistent with subsequent interpretations of geophysical observations cited above. The age of the subducting plate is assumed to be 8 to $10 \mathrm{Ma}$, simulating the condition of warm-slab subduction. The mantle wedge is isoviscous, with its most seaward portion (overlying the portion of the slab that is shallower than $50 \mathrm{~km}$ ) assigned a no-flow condition. The presence of a stagnant forearc mantle wedge corner is a commonly reported feature of subduction zones and is of critical importance for the stability of serpentinite (Wada and Wang 2009). Slab dehydration is expected to occur over a depth range from about 20 to $50 \mathrm{~km}$ in warm slabs based on seismological evidence (Kirby et al. 1996) and thermo-petrological arguments (Peacock 1993; Peacock and Wang 1999; Wada and Wang 2009). Limitations of this model concerning the size of the serpentinite region are discussed later in the present paper.

This starting model is, of course, a simplification of what is undoubtedly a complex structure of the California margin that has had a long history of accretion of oceanic sediment, mafic crust and ultramafic mantle during subduction in the late Mesozoic and early Tertiary. The essential features of our starting subduction model are that the forearc margin was petrologically stratified as mantle and crust (similar to that found in present-day Oregon and other subduction systems) just as subduction ended and that the California forearc mantle was at least partially serpentinized during its prior subduction history.

\section{Model mineralogical details}

We used as our model high-temperature/high-pressure hydration/dehydration reaction:

$$
\text { antigorite } \rightarrow 18 \text { forsterite }+4 \text { talc }+27 \mathrm{H}_{2} \mathrm{O}
$$

that has an equilibrium phase boundary determined from experiments (Evans et al. 1976; Ulmer and Trommsdorff 1995). Antigorite is the dominant serpentine mineral in the high-temperature alteration of olivine. We ignore the second-stage dehydration reaction involving talc at yet higher temperatures because it represents only $1.6 \mathrm{wt} . \%$ water loss compared to $10.7 \%$ for the above reaction. The properties of this model serpentine mineral, the other phases, and this dehydration reaction were extracted from the literature (including Robinson et al. (1983)) and are given in Additional file 1: Table S1.

This starting subduction model indicates that about $1,300 \mathrm{~km}^{3}$ per kilometer of margin of forearc mantle is within the stability field of antigorite. For simplicity and given the large uncertainties in estimating the degree of serpentinization from seismological observations, we follow Bostock et al. (2002) by assuming that this region is about $50 \%$ antigorite by volume. With an average compressed grain density of $2.6 \mathrm{Mg} / \mathrm{m}^{3}$ for antigorite (Additional file 1: Table S1) and the known water content of antigorite, this serpentinized mantle wedge represents about $180 \times 10^{6} \mathrm{~m}^{3}$ of stored water per meter of margin, an enormous potential deep source of free water if fully released into the crust above. 


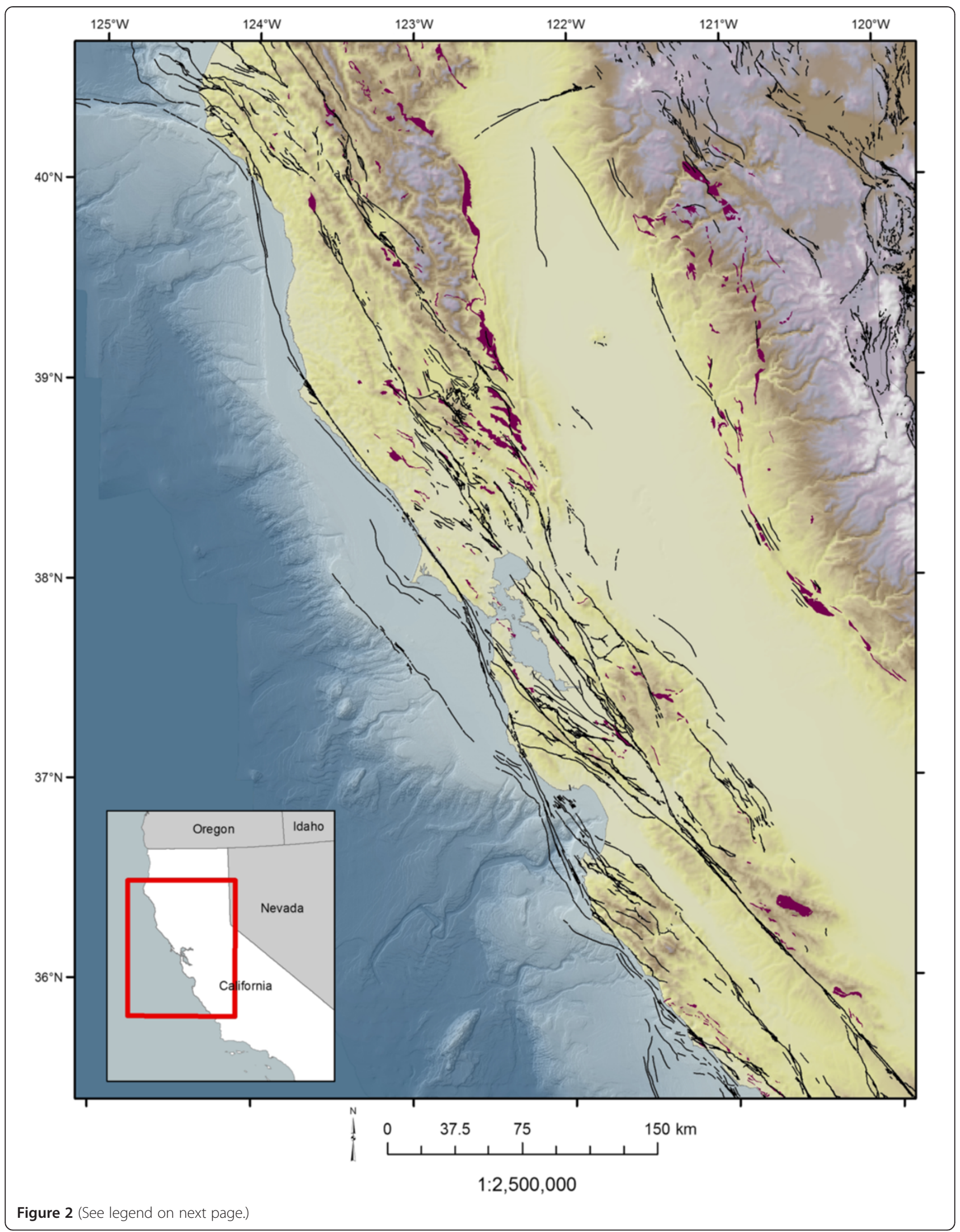


(See figure on previous page.)

Figure 2 Seismological and geological settings of San Andreas Fault System (SAFS) in northern California. Faults active during Quaternary time (black lines) and the distribution of serpentinite and other mantle rocks (reddish-brown areas) in the same region of northern and central California as in Figure 1 (Sources: 2010 Geological Map of California (Gutierrez et al. 2010; Jennings and Bryant 2010; USGS/CGS Quaternary Fault and Fold Database 2014). Note the close correspondence of the distribution of some of these rocks to the vicinity of strands of the SAFS and the similarities of the azimuthal trends of these bodies to nearby active faults.

\section{Post-subduction model assumptions: initial and boundary conditions}

Because there is not general agreement as to the evolving kinematics and detailed structure of the continental margin under California south of the MTJ, we adopt two end-member assumptions to describe the thermal condition under the former Cascadia forearc immediately after the passage of the MTJ (Figure 3). The starting model for the stalled slab assumption is merely the Cascadia subduction model discussed earlier (Figure 3a). The slab-gap model (Dickinson and Snyder 1979; Dickinson 1997) for the kinematics of the MTJ has a lithospheric gap develop under the North America Plate (i.e., the former forearc) that is filled by an upwelling of the asthenosphere (Figure 3b). The north-to-south change in heat-flow distribution and volcanic age progression of the Coast Range volcanics (younger to the north) are broadly consistent with this model (Furlong et al. 1989; Zandt and Furlong 1982; Liu and Furlong 1992; Dickinson 1997). We model the effects of this slab-gap assumption by simply replacing the former Farallon slab of the starting model with asthenosphere having an initially constant contact temperature that we individually modeled as $1,100^{\circ} \mathrm{C}, 1,200^{\circ} \mathrm{C}$, and $1,400^{\circ} \mathrm{C}$. Because subduction does not occur south of the MTJ, we assume that entrained asthenospheric circulation driven by slab motion is no longer occurring and hence we only allow conductive heat exchange between the forearc and the asthenospheric

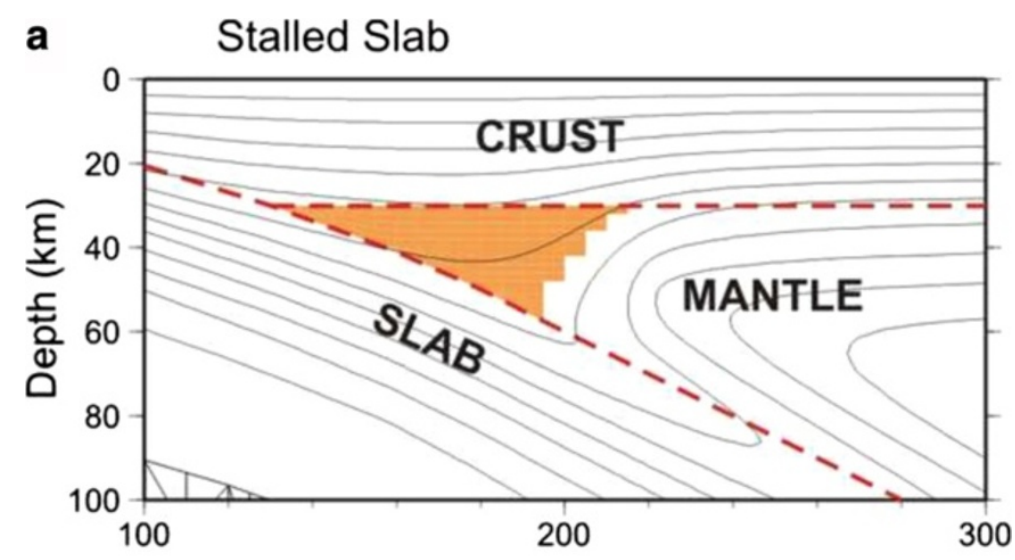

b Slab Gap

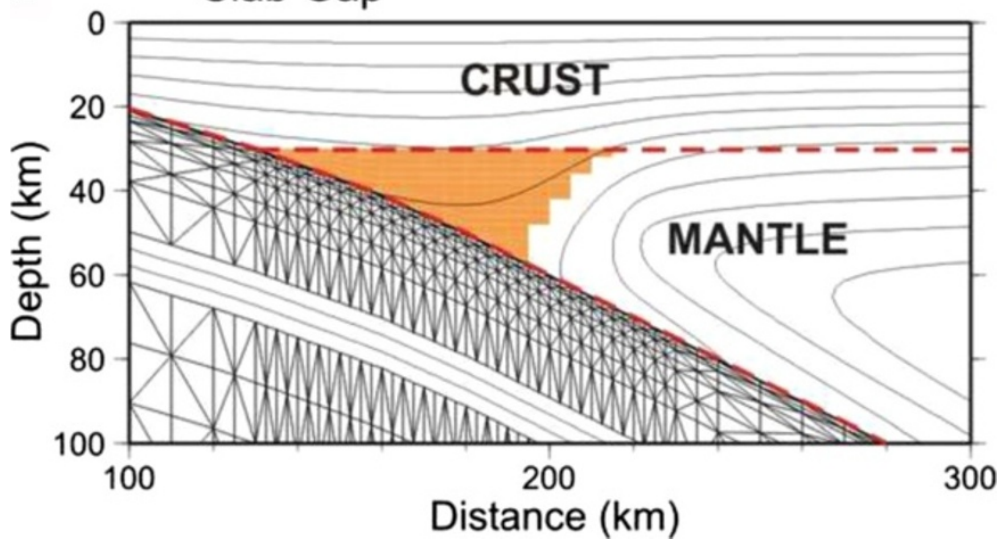

Figure 3 Starting thermo-mineralogical models. (a) Model for the southern Cascadia subduction system. Orange-shaded area represents the cold part of the forearc mantle within which the serpentine mineral antigorite is stable. The crustal thickness of the upper plate is $30 \mathrm{~km}$. The isotherms are plotted in $100^{\circ} \mathrm{C}$ intervals starting with the $100^{\circ} \mathrm{C}$ isotherm. The inclined dashed line is the top of the slab. See text for other details. (b) Starting slab-gap model showing the finite element grid in the slab and asthenosphere with an initial contact temperature of $1,100^{\circ} \mathrm{C}$. 
wedge; it cools down as the forearc heats up. This would seem more sensible than just assuming a constant asthenospheric boundary temperature, a condition that would presumably only be sustained by vigorous circulation in a rheologically weak asthenosphere that seems unlikely after slab descent ceases, especially at the lower initial boundary temperatures. The resulting thermal, mineralogical, and water-flux evolution based on this modeling effort are shown in Figure 4.

This slab-gap model has been questioned on the basis of other observations and insights (Bohannon and Parsons 1995; ten Brink 1999; Erkan and Blackwell 2008). Those authors have suggested that a stalled-slab structure for the California margin is more consistent with the geologic history of subduction and heat-flow observations in California than the slab-gap model. In their recent thermal modeling study, Erkan and Blackwell (2008) modeled both hypotheses and found that the slabgap hypothesis generally overestimates observed heat flows in the Coast Range (CR), Great Valley (GV), and Sierra Nevada (SN) provinces, whereas the stalled slab model underestimated the heat flow in the CR, but produced satisfactory fits to the GV and SN Provinces. Seismic investigations (Brocher et al. 1999) interpret the presence of an eastward-dipping regional mantle reflection in California, the PmP phase, and the absence of a conventional horizontal PmP reflection that is found to the east in the North American Plate as indicating that an inclined fossil Juan de Fuca slab still persists as far as $100 \mathrm{~km}$ east of the California coastline and about $150 \mathrm{~km}$ from the paleo-trench position (Figure 5). Moreover, an onshore-offshore seismic profile just south of the MTJ (Henstock et al. 1997) not only shows many examples of onshore slab PmP reflections, but also shows tomographic evidence for a wave-speed anomaly associated with a stalled slab. This east-to-west range for slab PmP reflections brackets the position of the segments of the SAFS. If this interpretation is correct, then an aseismic décollement may exist on the top of a stalled slab that links these shallow active strands of the SAFS kinematically with its unknown SAFS deeper structure. These considerations suggest that a stalled-slab assumption should also be considered, a condition that maintains the slab in conductive contact with the forearc above it. Its shortcomings are that it fails to supply a straightforward explanation of the late Cenozoic Coast Range volcanics and somewhat underestimates CR heat flows (Erkan and Blackwell 2008). To simulate the stalled slab scenario, the steady-state starting model described above is directly used as the initial condition for post-subduction cooling, but without renewed fresh contact of cold seafloor.

Using these simplifying assumptions, initial conditions, computational details, and material properties derived from laboratory measurements (see Additional file 1:
Table S1), we calculated for the two classes of thermal models (Figure 4): (1) changes in the temperature as a function of the time after passage of the MTJ, (2) changes in the distribution of antigorite as a function of time after subduction ceases as dictated by the phase diagram for antigorite, and (3) water production curves with time based on the changes in volume of the serpentinized forearc mantle.

\section{Results and discussion \\ Model results}

We show the thermal structures and antigorite serpentine distributions at $5 \mathrm{Ma}$ intervals after subduction ceased in Figure 4a,b and water production curves in Figure $4 \mathrm{c}$ for the two end-member model assumptions. For both models, dehydration begins almost immediately, and the periods of significant water production are on geological time scales, representing large fractions of the history of the SAFS and hence water release should have occurred at the roots of this active fault system over much, if not all, of its history. For the stalled slab model, initial water production is slower than in the slab-gap models and significant production continues to $25 \mathrm{Ma}$ and beyond. The serpentinized forearc wedge for the slab-gap model with initial basal temperature of $1,400^{\circ} \mathrm{C}$ (not shown) loses most of its water by $5 \mathrm{Ma}$ and yet continues releasing some water to $10 \mathrm{Ma}$. If we assume a lower boundary temperature of $1,100^{\circ} \mathrm{C}$, significant water loss continues to nearly $20 \mathrm{Ma}$ (Figure $4 \mathrm{~b}$ ). According to these model results, large quantities of stored water are liberated by dehydration of the serpentinized forearc mantle wedge. The low thermal conductivities of the relevant mantle and crustal minerals and the dimensional scale of this source dictate that this release of water into the shallower mantle and crust should occur over a broad near-coastal region of the California continental margin over a period of millions to tens of millions of years.

The predicted post-subduction lifetime of the serpentinized mantle body is very conservative and almost certainly an underestimate. Our starting models are based on the structure of the Cascadia subduction system in Oregon in which the depth of the Moho east of the serpentinite forearc mantle wedge is about $30 \mathrm{~km}$. However, Moho depths east of the California Coast Ranges and the San Andreas Fault System range from 22 to $30 \mathrm{~km}$ (Fuis and Mooney 1990). If we adopt a shallower Moho depth of $25 \mathrm{~km}$ for our starting model, the 'survival time' of the serpentinized body will be prolonged by at least 10 million years, because the warming up of the colder, shallower part of the system is extremely slow. A shallower Moho in the starting model also means that the starting volume of serpentinized forearc mantle would also be larger, and more water would be released into the fossil forearc crust. 
a

(a) Stalled Slab
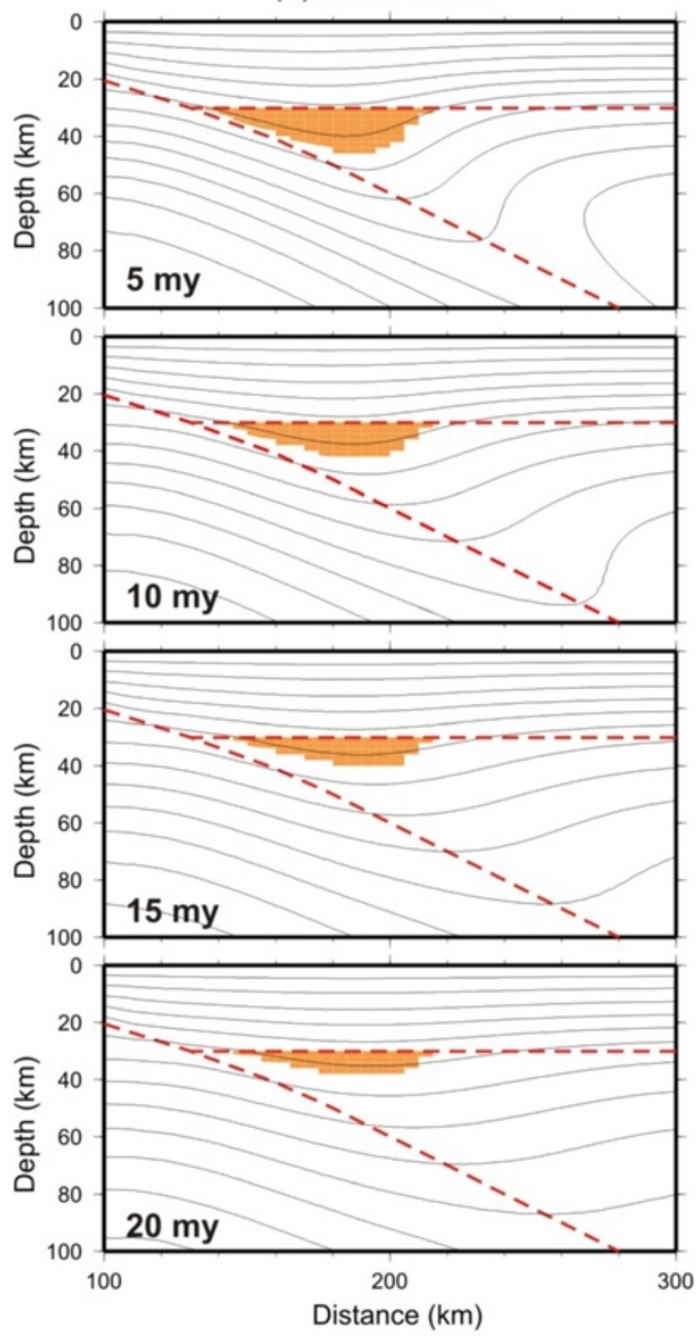

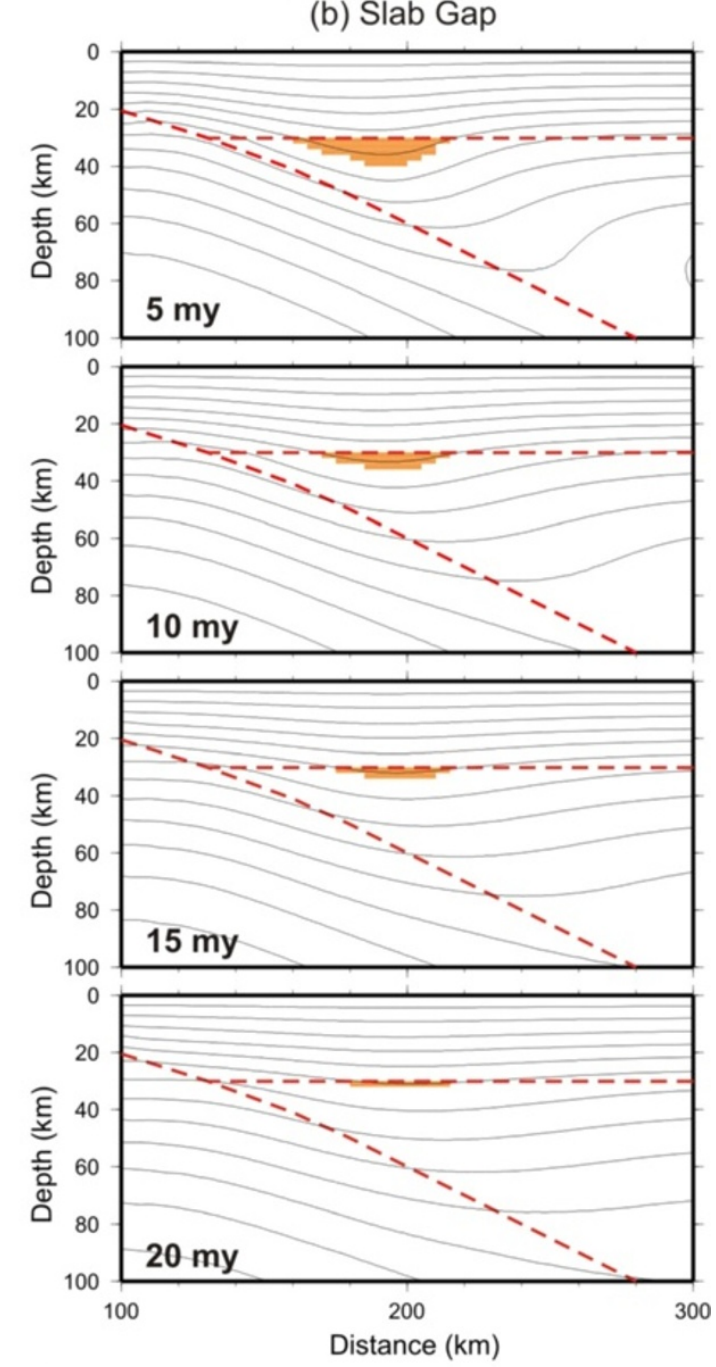

b

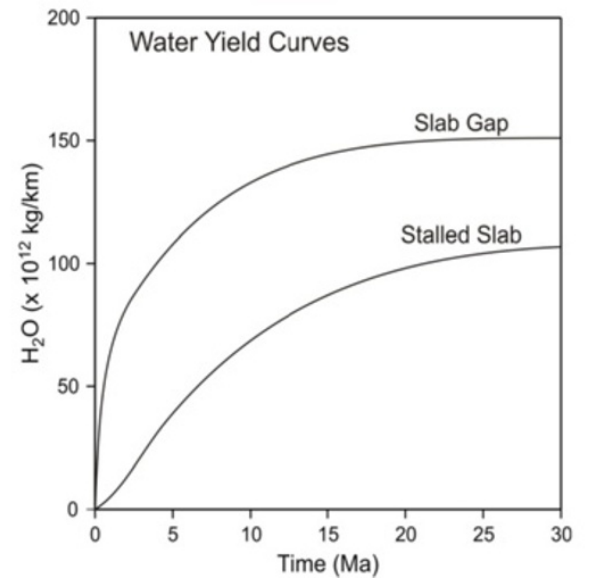

Figure 4 Model results showing predicted changes in the distribution of serpentine at $\mathbf{5}$ Ma time intervals. (a) Stalled-slab boundary condition; (b) Slab-gap thermal boundary condition with an initial $1,100^{\circ} \mathrm{C}$ boundary temperature (the inclined dashed line represents the bottom of the former forearc in both (a) and (b). (c) Water production curves with time for both models. Note the geological time scale over which water is released into the former forearc. 


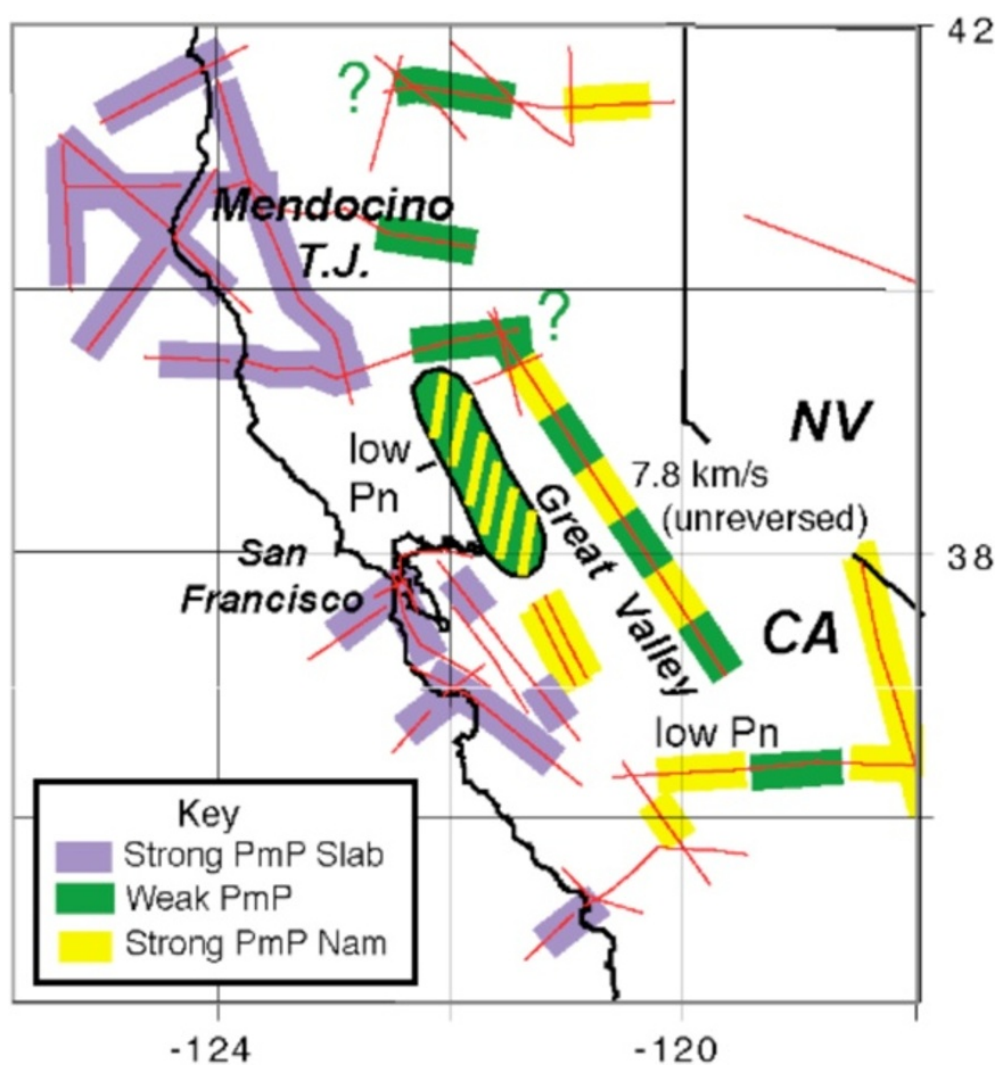

Figure 5 Map of the locations of seismic profiles for northern California. This shows segments exhibiting strong slab mantle reflections (the phase PmP, a downward P wave that reflects at the top of the mantle, $\mathrm{m}$, and returns to the surface as a P wave) near the coastline (purple lines), those with weak PmP (green), and those having strong PmP reflections along inland profiles in the North America Plate (Nam, yellow). Seismic lines with observed intermediate-amplitude PmP reflections are shown as dashed or hatched yellow/green lines.

Assuming a different degree of mantle serpentinization before the cessation of subduction will change the rate and amount of water production, but it will not change the 'survival time' of the serpentinized fossil forearc. An issue that may affect the water production rate is postsubduction hydration of the shallow part of the serpentinized mantle wedge, a process not explored by our modeling: As the system warms up after the cessation of subduction, the dehydration phase boundary gradually migrates upward from the warmer bottom of the serpentinized body into the colder, shallower part of the wedge (Figure 4). Fluids released from the dehydration boundary would move upward to cause further serpentinization in the region where antigorite is still stable. The effect of this process is to reduce the rate of water production in the early part of the post-subduction history, when some of the water is consumed in the continuing hydration of the shallow part of the ancient mantle wedge, and to increase the rate in the later part of the history, when the degree of serpentinization of the remaining, shallower region of the ancient wedge has become higher. This effect should extend the lifetime of the serpentinized fossil forearc mantle.

\section{Implications for the SAFS}

\section{General relevance}

An important question is how applicable is our starting slab subduction model based on the present-day structure of the Cascadia subduction system to the California margin prior to creation of the SAFS. Radiogenic age dates of the granitic arc magmatic rocks in the Sierra Nevada become younger from west to the east with the youngest being about $80 \mathrm{Ma}$ at the Sierran crest near the eastern front (Moore 2000). From that time, the magmatic arc of California became inactive south of the present-day Cascade arc even though subduction evidently continued along the California margin until the birth of the SAF at about $30 \mathrm{Ma} \mathrm{BP}$. This shift to an amagmatic arc is widely interpreted as a change to a near-horizontal subducting slab by a depth of about 100 to $150 \mathrm{~km}$, similar to the present-day avolcanic flat-slab segments of Peru and northern Chile. The Laramide orogenic belt is thought to have been a far-inland tectonic expression of flat subduction, but Laramide tectonic activity largely ceased by about 80 to $55 \mathrm{Ma} \mathrm{BP}$ depending on the latitude. What was the subduction structure from 55 to $30 \mathrm{Ma} \mathrm{BP}$ in the time interval just 
before the San Andreas system was created? One possibility is that as the Pacific-Farallon spreading system approached the California segment of the FarallonNorth America trench, warm-slab conditions began to prevail and the system became amagmatic; very low arc volcanism is a common character of warm-slab subduction (Kirby and Wang 2002). In very-warm-slab subduction zones, water release from the slab should occur at shallow depths, a condition that should favor serpentinization of the forearc (Kirby et al. 1996; Peacock and Wang 1999; Hacker et al. 2003; Wada and Wang 2009). Thus, the average pre-subduction slab dip could well have been in the range $20^{\circ}$ to $30^{\circ}$ as is found in present-day warmslab settings such as Cascadia and the starting thermomineralogical model that we have adopted.

A variety of geophysical observations are consistent with our model (Figures 6 and 7). According to the interpretation of Fuis and Mooney (1990), seismic refraction and reflection data for central California show that the depth to the Moho varies from $22 \mathrm{~km}$ near the coast and gently deepens to about $30 \mathrm{~km}$ to the east. Above the Moho, they infer the presence of mafic lower crust from about $12 \mathrm{~km}$ down to their Moho with compressional wave speeds of 6 to $7 \mathrm{~km} / \mathrm{s}$. Godfrey and others (1997) conclude, on the basis of a variety of geophysical and seismic data, that the Great Valley and eastern Coast Ranges are underlain by oceanic crust that is attached to a layer of altered upper mantle. The western limit of this mafic/ultramafic structure is not well constrained. These data may be reinterpreted in light of the recent findings consistent with the presence of a partially serpentinized forearc mantle in the Cascadia subduction system and elsewhere cited earlier. If the 'Moho' in these earlier studies is actually the Moho in the stalled fossil slab, then the material just above it that has intermediate wave speeds (6 to $7 \mathrm{~km} / \mathrm{s}$ ) and was previously interpreted as 'lower crust', could be reinterpreted as a thin, partially serpentinized ultramafic mantle. A broad magnetic anomaly in northern California has been modeled and interpreted as defining an 'ophiolitic' magnetic basement underlying the Franciscan crust that extends at least as far west as the Hayward fault (Jachens et al. 1995; Godfrey et al. 1997; Ponce et al. 2003a,b) (Figure 7). Brocher and others (1999) reinterpreted previously identified Moho reflections in northern California as reflections on fossil slab material (Figure 5). If this inclined fossil-slab interpretation is correct, then this magnetic basement with intermediate seismic wave speeds may be a thin, almost flat-lying body of partially serpentinized mantle. It must be emphasized, however, that the present-day structure of the California margin has been much modified by San Andreas/Coast Ranges tectonic, magmatic, and volcanic processes, making it difficult to be very confident of its detailed paleo-subduction structure.

According to our models, a wedge-shaped water source has existed in the mantle along the present-day California continental margin for the last 30 million years and this source has led to a broad, long-term upwelling of water near the roots of the present-day SAFS. As discussed earlier, the permeabilties estimated from the maximum fluid flux from our models are high enough for high fluid pressures to be generated, but not so high that fluid heat advection should be important and hence no hot springs are expected. However, Murata et al. (1979) documented diagenetic changes in silica mineralogical forms in Miocene shales that they attributed to modest transfers of heat (with $\Delta T$ approximately $15^{\circ} \mathrm{C}$ ) from nearby intrusive serpentinites. Also, hydrothermal alteration of serpentinites to silica-carbonate rocks and mercury ore minerals are commonly found in the Coast Ranges (Barnes et al. 1973;

\section{SAFOD Hole Location}

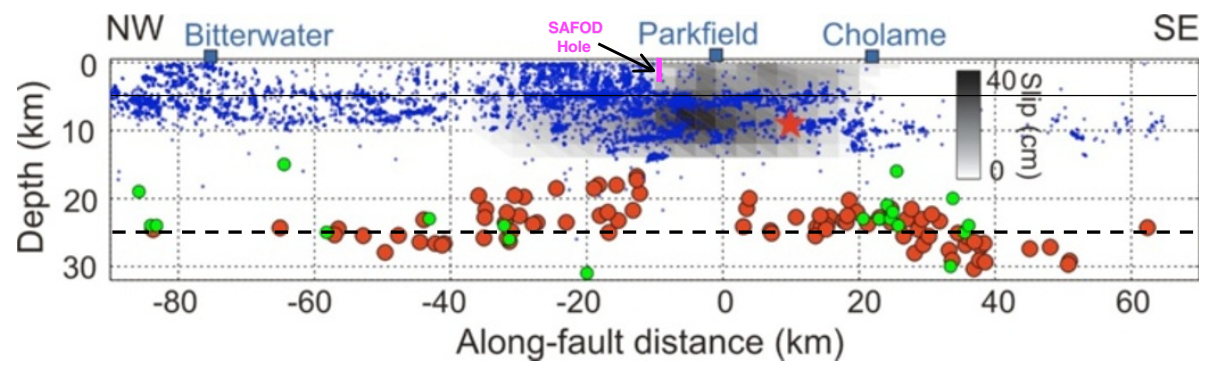

Figure 6 Structure of seismogenesis along a segment of the San Andreas Fault in central California. This figure shows a comparison of the non-volcanic tremor (NVT) zone and seismogenic zone along the San Andreas Fault (SAF) (modified from Shelly and Hardebeck (2010); segment location shown in Figure 1). The star represents the hypocenter of the 2004 M6 Parkfield earthquake, and the shading shows the area of its combined coseismic slip and first 230 days of postseismic slip (Murray and Langbein 2006). Blue dots represent the hypocenters of regular earthquakes provided by D. Shelly. Red and green circles are ambient and teleseismically triggered tremor from Waldhauser and Schaff (2008) and Peng et al. (2009), respectively. The Moho depth is about $25 \mathrm{~km}$ (dashed line). Magenta line shows the projected location and maximum depth of the SAFOD scientific drill hole. 


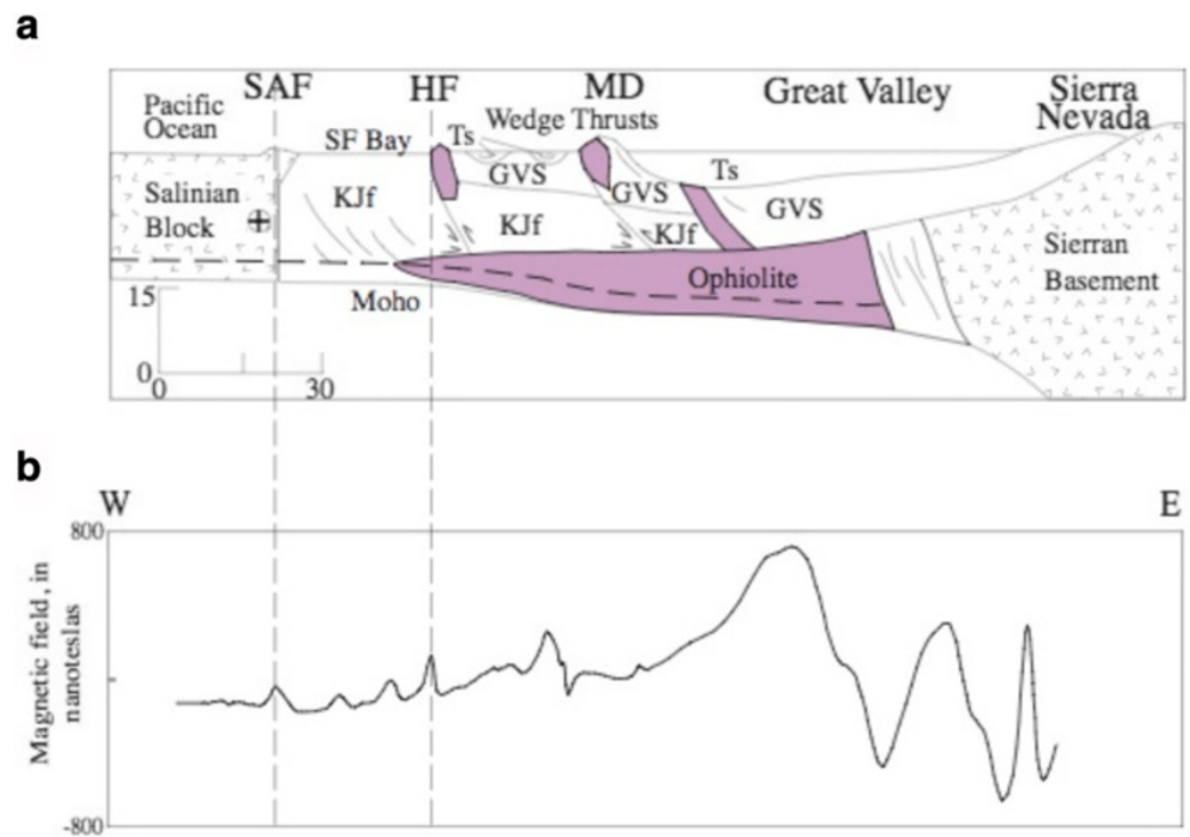

Figure 7 Interpretive geophysical cross section for central California. (a) Published magnetic and seismic interpretations along section location indicated in Figure 1 (San Francisco Bay) based on the interpretations of Fuis and Mooney (1990) and Ponce et al. (2003a,b, 2008). The region labeled 'ophiolite' represents accreted oceanic lithosphere (by our interpretation, partially serpentinized mantle with or without altered crust) that is, according to this paper, now dehydrating. The MTJ passed through this area at approximately 10 Ma BP. HF, Hayward Fault; MD, Mount Diablo; SAF, San Andreas Fault; CRO, Coast Range ophiolite; Kjf, Franciscan Complex; GVS, Great Valley sequence; Tsd, Tertiary sedimentary rocks. The top of a possible stalled Farallon slab is shown as a dashed line, as suggested by the seismic evidence in Figure 5. (b) Magnetic profile along cross section in Figure 2. Sharp magnetic peaks generally correspond to outcrops of largely serpentinite-bearing bodies and shallow subsurface distributions of such rocks, often along faults in the San Andreas Fault System. The main trend of the magnetic field has been modeled according to the structure shown in (a). The distribution of serpentinites in the shallow crust may be associated with vertical mobilization of serpentine from serpentinized former forearc mantle by release of water by a mechanism suggested in this paper.

Rytuba 1986) and are usually ascribed to the effects of water/carbon-dioxide fluids of likely mantle origin similar to those that occur locally in springs along the San Andreas Fault (Irwin and Barnes 1980; Kennedy et al. 1997; Kharaka et al. 1999).

Our starting model could have a shallower forearc crust-mantle boundary and hence a thicker, longer-lived serpentinite wedge after subduction ceased. Moreover, we do not know in detail how the SAFS evolved and specifically what have been the fluid pathways in the crust above the dehydrating wedge over time. The inferred proximity of this hypothetical dehydrating forearc water source to the SAFS suggests that this may be the inferred deep water source discussed by others and cited earlier in this paper. As discussed earlier, this water source could allow the SAFS to slip at low stresses by reducing the effective normal stress along its different strands at depth or by other deformation processes facilitated by hydrothermal conditions. This broad (about 50 to $80 \mathrm{~km}$ for our specific model assumptions) water source is very large in total mass, and its release into the crust is expected to be long lasting. The breadth of the source region may provide insight into the distributed fault slip among the segments of the northern SAFS. Migration of pressurized water from such a broad source may facilitate fault slip at low stresses in a broad plate boundary zone over much of its history rather than along a single, sharply defined plate boundary fault. The inherent weakness above such a zone of deep water upwelling may also help us understand why the SAFS did not nucleate and grow at or near the paleo-trench position in Pacific-Plate oceanic lithosphere. We do not know how the strands of the SAFS might have nucleated and ascended through the former forearc crust from this mantle source of water or by what means fluid pathways along pre-existing forearc faults may have been exploited.

\section{Fluid transport}

Expected fluid pressures depend on water supply rates in relation to the permeability of the crust above along the fluid pathways. We estimate that the average discharge rates through the crust implied by our models correspond to temporally and spatially averaged deep permeabilities of 0.4 to $1.3 \times 10^{-18} \mathrm{~m}^{2}$. This range of permeabilites is, in turn, comparable with values inferred from modeling of prograde metamorphism at depths 
greater than about $15 \mathrm{~km}$ (Manning and Ingebritsen 1999; Ingebritsen and Manning 2010) and from phyllosilicaterich and fault rocks in the laboratory (Faulkner and Rutter 2001). Presumably, such permeabilities are sustained by fractures developed at fluid pressures near lithostatic and are transient in the absence of ongoing tectonic deformation. Fault-zone materials themselves could maintain such low permeabilities during pre-earthquake regimes of the earthquake cycle as a consequence of time-dependent porosity- and permeability-reducing processes, such as compaction creep and mineral precipitation (Sleep and Blanpied 1992). Manning and Ingebritsen (1999) also conclude that the depth trends of inferred permeabilities in the continental crust straddle those in which heat transfer occurs largely by conduction (as verified by the absence of hot springs along the SAFS (Sass et al. 1997)) and those minimum permeabilities required for solute transport that allow crystallization of secondary minerals that could shut off fluid transport at depths shallower than $15 \mathrm{~km}$.

These comparisons are encouraging in that the water supply rates predicted by our thermo-mineralogical models may be adequate to support fluid pressures approaching the lithostatic normal stresses and, in turn, low in-situ resistance to fault slip along the strands of the SAFS. Given the uncertainties discussed above and the limitations of the thermo-mineralogical models of this paper, we view the possible connection of this deepwater source and the roots of the San Andreas Fault System as very promising hypothesis that deserves additional investigation and testing. Fulton and Saffer (2009) have gone way beyond the above crude analysis and have quantitatively assessed the potential for the discharge from the serpentinite wedge to produce high fluid pressures in the vicinity of the SAF. Using advanced estimates of permeability and crustal structure, these authors show through numerical modeling that localized high fluid pressures can develop along the SAF given the average discharge rates from our models.

The San Andreas Deep Fault Observatory drilling operations penetrated into the active creeping segment of the SAF at a depth of approximately $2.6 \mathrm{~km}$ near Parkfield, California (Zoback et al. 2011). No evidence for highly pressurized fluids was found at this site. Several comments are relevant to this important finding. First, the segment of the active SAF exhibits shallow creep behavior with seismic moment largely deeper than the SAFOD true penetration depth (Figure 6), and hence this sampling of the SAFS may not be typical of its seismogenic zone. Second, secondary hydrous minerals were observed in the drill core that penetrated the active segment of the fault, indicating that aqueous fluids were present in the zone at some time in the recent past. Some hydrous minerals, such as talc (Moore and Rymer 2007) and clay minerals (Schleicher et al. 2006; Schleicher et al. 2010) are weak shear-zone materials and may be responsible for fault creep behavior. Finally, our model does not preclude the possibility that fluid flow through the crust from the shrinking serpentinite mantle wedge could be episodic as affected by tectonic and seismic activities and that our estimates of long-term average water discharge rates do not reflect the possibility of transient fluid transport.

We will also discuss in section 'Tectonics of California serpentinite in light of this model' the occurrence of secondary serpentine minerals in exposed serpentinite blocks along the SAFS as indirect evidence for largescale fluid migration from the mantle along the SAFS.

\section{Relevance to tremor observations along the central SAFS}

The recognition of the presence of a dehydrating serpentinized mantle wedge is potentially important for understanding the occurrence of low-frequency seismic tremor along the SAFS. Seismic tremor commonly occurs in the forearc of Cascadia and Nankai subduction zones (Rogers and Dragert 2003; Obara 2002). It is also reported for a few other subduction zones such as Mexico, Costa Rica, and Alaska (Peng and Gomberg 2010). It is distinctly different from seismic tremor associated with magma activity beneath volcanic arcs and therefore is called non-volcanic tremor (NVT). The seismic tremor observed along SAFS is similar to the subduction-zone NVT, although the signal is much weaker and the level of activity is much lower (Nadeau and Dolenc 2005; Shelly and Hardebeck 2010; Gomberg et al. 2008; Peng et al. 2009; Thomas et al. 2009). Figure 6 shows examples of SAFS tremor, including those triggered by seismic waves of remote large earthquakes and those that occur spontaneously without obvious triggering mechanisms.

It is intriguing why NVT occurs along the SAF that is not presently a subduction boundary. The locations of SAFS tremor sources shown in Figure 6 may provide some clue to resolving this puzzle. These tremor sources are located mostly in the depth range of 25 to $30 \mathrm{~km}$, significantly deeper than the seismogenic zone that produces regular earthquakes (Figure 6), and appears to be associated with processes in the mantle (Shelly and Hardebeck 2010). It is important to recognize that subduction zone NVT occurs mostly in the depth range of 30 to $50 \mathrm{~km}$ and appears to be strongly correlated with the spatial position of the tip of the posited mantle wedge in our model. Subduction zone NVT has been associated with a highly serpentinized mantle wedge, typically in warm-slab subduction zones (Wada et al. 2008). If serpentinites in the mantle wedge and the abundance of free fluids from the dehydrating slab are responsible for generating the NVT (Ide et al. 2007; Ide 2010), it is then not difficult to see why tremors could also occur along the SAFS. The presence and dehydration of the 
serpentinized mantle material at Moho depths along the SAFS should give rise to a similar condition for fluid migration as found near the mantle wedge tip in active warm-slab subduction zones. Compared to Cascadia and Nankai, the slow, late-stage rates of fluid migration from the shrinking serpentinite wedge suggested by our model results (Figure 4) are consistent with the tremor signal at Parkfield being much weaker than in these subduction zones. The reasons behind why present-day NVT seems to be localized in central California between San Juan Bautista and Cholame are not known.

\section{Tectonics of California serpentinite in light of this model}

Serpentinite in our hypothesized hydrated forearc mantle is gravitationally unstable because serpentinites are less dense than most crustal rocks under crustal P-T conditions (Christensen and Mooney 1995). The nearcoastal region of the former forearc broadly coincides with the surface distribution of the serpentinite tectonic blocks and slivers and diapirs in forearc crustal rocks (Figure 2) as well as 'sedimentary' or 'mud' serpentinites that were thought to be part of a mélange of serpentinites erupted on the seafloor in the oceanic basins (Barnes et al. 2013), like those observed in some modern subduction zones, such as the Marianas (Fryer et al. 1985; Murata et al. 2009; Wakabayashi 2011). Field relations in California indicate some of the diapiric or fault-bounded serpentinites were emplaced in the late Cenozoic (Bailey and Everhart 1964; Dickinson 1966; Coleman 1971, 1977, 2000; Murata et al. 1979; Page et al. 1999; Wakabayashi 2004, 2005, 2012; Wakabayashi and Dilek 2011; Wakabayashi et al. 2010). The common local occurrence of blocks of mantle peridotite, blueschists, and/or eclogites in such Neogene emplacements suggest that these serpentinite bodies may have originally come from deep crustal and/or mantle depths and were entrained with serpentinite ascent during the formation and lengthening of the San Andreas Fault System.

Contrary to expectations based on its low Mohs scratch hardness, serpentines, serpentinites and serpentinized peridotites deformed in the lab are surprisingly strong in the absence of free water. At confining pressures of a few kilobars or more and temperatures below $400^{\circ} \mathrm{C}$ to $500^{\circ} \mathrm{C}$ (i.e., within the serpentine P-T stability fields) experiments show that serpentinites are ductile, but have ultimate triaxial strengths of 0.5 to $1.4 \mathrm{GPa}$ at $T<400^{\circ} \mathrm{C}$ (Raleigh and Paterson 1965; Murrell and Ishmail 1976; Moore et al. 1997; Hirth and Guillot 2013). When deformed at higher temperatures outside the stability field of serpentine while dehydrating, serpentinites form faults that slip at far lower stresses. This embrittlement is understood to be associated with the reduction of effective normal stresses by fluid pressure (Raleigh and Paterson 1965). Moreover, in the absence of pressurized pore water or adsorbed water, coefficients of friction of serpentine gouges and serpentineserpentine sliding surfaces range from 0.6 to 0.7 under crustal conditions (Moore et al. 1996, 1997; Hirth and Guillot 2013), a range that brackets most other silicate rocks. Rock stresses in deforming serpentinites that are controlled by dry frictional resistance should therefore be high. The apparent tectonic mobility of serpentinites inferred from field observations has been an enigma from this rock mechanics perspective and the role of water released by serpentine dehydration has long been suspected as a solution to this enigma (Raleigh and Paterson 1965). We suggest that our proposed deep dehydration source of pressurized water in the forearc mantle could help mobilize upward migration of blocks of forearc mantle serpentinites above this water source, driven in part by buoyancy due to their low density, from the forearc mantle wedge and from ultramafic material in the crust above by reducing the effective normal stress along faults bounding these serpentinized blocks or slivers. The production of weak alteration products during ascent of such fluids, such as talc, chrysotile, clay minerals, and brucite, may also play a supplementary role in fault zone weakening, as suggested by others (Moore et al. 2004; Schleicher et al. 2010). The close relationships between some serpentinite blocks and their associated magnetic anomalies on the one hand and the active faults in the SAFS on the other (Figures 1, 2, and 7) suggests that emplacement may occur through mobilization of such bodies from depth by fluids generated by the process described earlier in this paper.

Indirect evidence of the presence of such fluids comes from the common occurrence of different crystalline forms of serpentine (antigorite, lizardite, and chrysotile; O'Hanley 1996; Deer et al. 2009) in the same serpentinite outcrop, suggesting multiple stages of mineral formation over different temperature ranges. Based on thermodynamic modeling and experimental observations, antigorite is considered the high-temperature/ high-pressure form of serpentine that results from a reaction of peridotites with water at mantle depths (Evans et al. 1976; Evans 2004; Schwartz et al. 2013). Chrysotile is a low-temperature, fibrous form of serpentine and often occurs in 'veins' or systems of veins that bound antigorite blocks (Evans 2004). As such, they resemble quartz vein fillings in crustal rocks that are widely interpreted as opening-mode (extensional) fractures that have been enabled by pressurized solute-laden aqueous fluid flow into such fractures at near-lithostatic pressures and subsequent quartz crystallization. Lizardite is a third form of serpentine minerals that is thought to form at temperatures intermediate to those for antigorite and chrysotile and, like chrysotile, can also be secondary to antigorite. This form of serpentine has a scaley or platy 
habit and is often found in shear zones bounding blocks of antigorite. A recent petrological study of a diapiric serpentinite body near Redwood City, California that is locally bounded by a strand of the San Andreas Fault System shows at least two major stages of serpentinization that the authors interpret as representing in situ mantle serpentinization to antigorite plus brucite followed by a lower-temperature serpentinization to lizardite, chrysotile, and magnetite under intense deformation during ascent of the body (Figure 8) (Uno and Kirby, The Redwood City Diapiric Serpentinite: An Integrated Petrologic and Tectonic Investigation, Unpublished Report, 2014; Kirby and Uno 2013, 2014). The time of diapiric emplacement is post-Eocene, but the lack of younger rocks in contact with the body makes it difficult to constrain the emplacement age more closely. Geological evidence elsewhere indicates that some diapiric serpentinite bodies along the SAFS have been emplaced in late Cenozoic (Neogene) time (Bailey and Everhart 1964; Murata et al. 1979; Coleman 1996; Page et al. 1999).

The low solubility of these silicates in water even at high temperatures and pressures requires a large volume flux through systems of fractures to allow appreciable mineral crystallization and vein thickness. Sibson (1996, 2002) concludes from fracture mechanics considerations and geological observations that such extensile structures form under fluid pressures exceeding the least principal compressive stress and that such conditions are obtained only where host-rock porosity is low so that fluid pressures can build up to near lithostatic. Antigorite cores and later-stage block-bounding lizardite and chrysotile veins indicate that high-fluid-pressure conditions under tectonic stress existed in such serpentinite bodies. These observations suggest to us that the chrysotile and lizardite grow by crystallization from aqueous solution during the ascent of serpentinite blocks that were mobilized by water release from the shrinking forearc serpentinite wedge. Evans (2004) suggests that these secondary serpentine minerals can form at temperatures as high as $400^{\circ} \mathrm{C}$, thermal conditions that are appropriate for the seismogenic zone in the SAFS and Coast Range Thermal Province (Sass et al. 1997).

The simplified hypothesis discussed above is not incompatible with the view that the former California forearc is made of accreted oceanic lithospheric terranes, both crust and mantle, brought in during an earlier regime of subduction (see review by Coleman (2000)). Post-subduction mantle components of such terranes would be subject to the same constraints of continuous cooling by subducting oceanic lithosphere, release of water from the slab, and serpentinization as described above. After subduction ceased with the northward migration of the MTJ, warming by conduction would similarly shrink such serpentinite and release water into the former forearc. However, the three-dimensional distribution of serpentinized mantle and serpentinite decomposition would be much more complex than envisioned here.

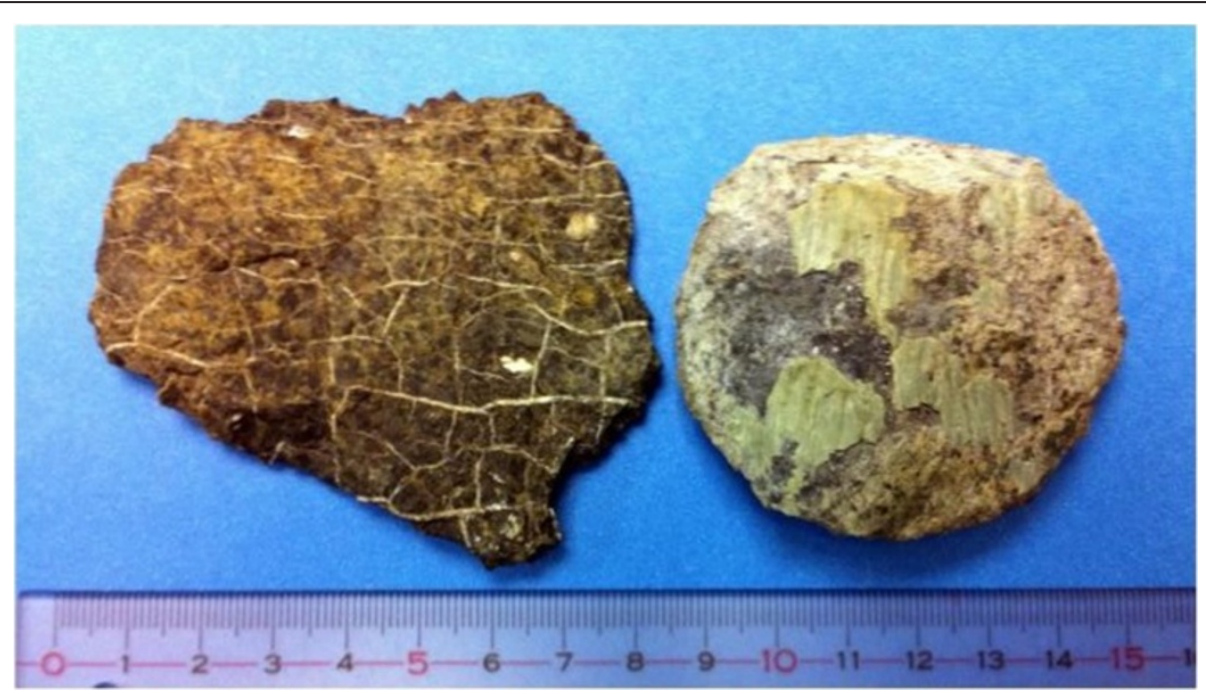

Figure 8 Hand specimens of two samples from a serpentinite outcrop. Left - the serpentinite core (dull green) and network of late-stage, low-temperature chrysotile vein filling (shiny fibrous growth) in a serpentinite block. Right - a shear zone that is comprised of later-stage sheared lizardite that bounds a block of massive serpentinite. Both samples collected from a member of a belt of diapiric serpentinite bodies along the San Andreas Fault above the town of Redwood City, California. The presence of chrysotile and lizardite in veins and shear zones that cross cut and bound antigorite blocks supports the hypothesis that vertical mobilization of such serpentinized mantle rocks was enabled by water released from forearc serpentinite that is described in this paper. Consequent partial dissolution of serpentine components occurred into this fluid at mantle depths, and subsequent lizardite and chrysotile serpentine crystallization is thought to have been enabled by this fluid during serpentinite-block ascent to the surface through the depths corresponding to the seismogenic zone of the SAFS. 


\section{Implications of this model elsewhere}

The concept of vertical mobilization of deep serpentinized forearc mantle with fossil forearc warming (Figure 9) may also give insights into the regional associations of some present-day strike-slip, transpressive, or collisional plate boundaries and ancient plate boundaries marked by serpentinites and other mantle and deep crustal rocks found where changes in plate motions or settings may have rendered unstable serpentinized forearc mantle produced during subduction. Possible examples include continental collision zones and suture zones (Seno and Kirby 2014), as well as the serpentinite belts near the North Anatolian Fault System in Turkey, some serpentinites near strikeslip faults in the Northern Greater Antilles from the Dominican Republic to Cuba (e.g. Saumur et al. 2010), subducting spreading centers near triple junctions, and other tectonic settings with similar tectonic histories where mantle-derived serpentinite rocks are found on Earth's surface near active subduction boundaries or along other paleo plate boundaries.

\section{Conclusions}

This paper is based on the premise that the region of the SAFS along the continental margin of California was in Mesozoic and Paleogene time an active subduction system with mineralogical and tectonic structure similar to that in the present-day Cascadia subduction system and that there existed a wedge-shaped part of the forearc mantle nearest the trench that was partially serpentinized, as is the case of the present-day Cascadia system. This serpentinized region represented an enormous amount of stored water. After subduction ceased with the northward migration of the Mendocino Triple Junction and creation of the SAFS, this serpentinized wedge, thought to be largely antigorite, began to warm up and release water into the crust above it. Numerical modeling of this process reported in this paper shows that the rate of water release is slow and persists over a large fraction of the history of the SAFS. These results give several insights into the SAFS and California geology and elsewhere:

- The range of modeled water discharge rates and average permeability estimates over time are consistent with estimates from previously published studies of prograde metamorphism at high fluid pressures relative to the lithostatic pressures and imply low resistance to frictional sliding along SAFS segments.

- According to our numerical model, the duration of significant water discharge from the mantle by this mechanism spans most, if not all, of the history of the SAFS.

- The resultant weakness of the California continental margin helps explain why the SAFS did not establish itself within the offshore Pacific Plate in oceanic lithosphere, but instead was distributed in the former forearc where water release from the forearc mantle rendered faults weak in the evolving SAFS.

- The breadth of the region over which water is released from the shrinking serpentinite wedge gives insight into why the SAFS plate boundary is so broadly distributed into a system of faults.

- The occurrence of fault-emplaced and diapiric serpentinite bodies from mantle depths that are exposed at the surface in the California Coast Ranges and inferred to be at depth from magnetic and gravity anomalies is explained by serpentinite mobilization by near-lithostatic fluid pressures implied by our model (Figure 9).

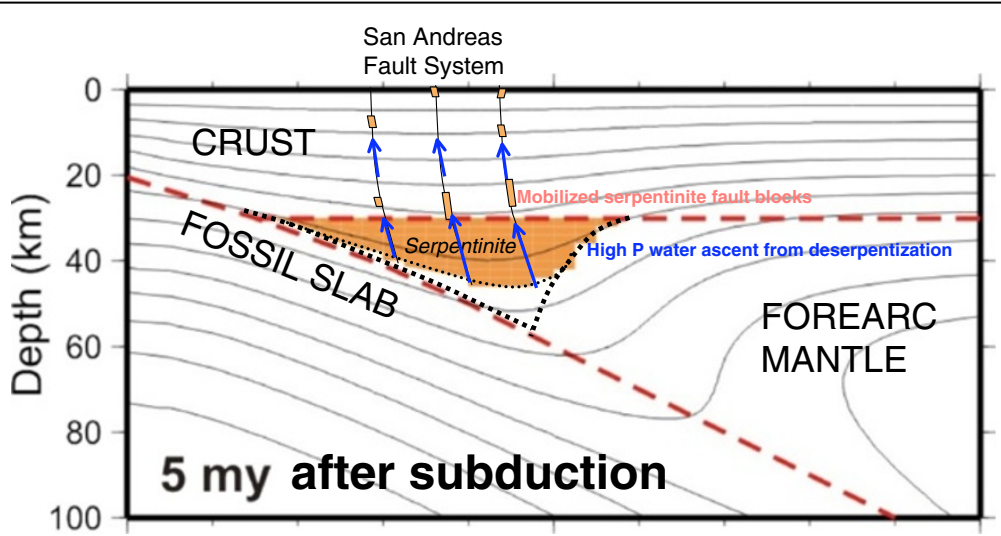

Figure 9 Schematic diagram illustrating the possible mobilization of serpentinite bodies by the process described in this paper. These bodies, occurring as fault blocks, slivers, and diapirs shown in orange, are thought to come from the fossil forearc mantle. Their ascent is enabled by the release of pressurized water from the base of the serpentinized fossil forearc mantle wedge caused by the thermal decomposition of wedge during conductive heating after subduction ceased, a process modeled in this paper. The fluid pressures generated by this model are also implicated as the source of high fluid pressures that could reduce the resistance to frictional sliding along the segments of the San Andreas Fault System. 
- The presence of low-temperature forms of serpentine: chrysotile and lizardite, in such serpentinite bodies is considered geologic evidence that these minerals crystallized from solute-laden aqueous fluids that accompanied the ascent of these serpentinites from the serpentinite wedge through depths corresponding to the seismogenic zone of the SAFS.

The processes summarized above may have also occurred in other tectonic settings where subduction was arrested and the serpentinized mantle wedge becomes thermally unstable, such as in collision zones and continental transforms following subduction and where oceanic ridge crests are subducting.

\section{Additional file}

Additional file 1: Table S1. Details of the mineralogical model. S2 Details of the computational model.

\begin{abstract}
Abbreviations
MTJ: Mendocino Triple Junction; Nam: North America Plate; NVT: non-volcanic tremor; PmP: the body-wave seismic phase representing a compressional (P) wave reflection off the crust-mantle boundary; SAF: San Andreas Fault; SAFS: San Andreas Fault System the ensemble of tectonically active offshore and onshore faults between the western edge of the Great Valley of California and the base of the offshore continental slope along which the Pacific: North America plate motion occurs; SAFss: San Andreas Fault sensu strictu the chief member of the San Andreas Fault System where tectonic slip rates are highest.
\end{abstract}

\section{Competing interests}

The authors declare that they have no competing interests.

\section{Authors' contributions}

SHK conceived the conceptual model, compiled the mineralogical data as inputs to the numerical models, developed most of the applications to California earthquake physics and the geology of serpentinites, and was the lead writer of the various drafts of this paper. KW set up the initial subduction thermal model and the post-subduction boundary conditions and performed the numerical calculations, the results of which form the basis of this paper. He also reviewed, compiled, and interpreted the information on non-volcanic tremor along the SAFS. Both participated in discussions and final writing of this paper. TMB provided some important insights into the seismic structure of California relevant to this paper, especially into the interpretation of the PmP seismic phase. All authors read and approved the final manuscript.

\section{Acknowledgements}

We benefited from discussions with our colleagues Roy Hyndman, Richard Blakely, Bob Jachens, David Ponce, Uri ten Brink, Art McGarr, Ray Wells, Tom Parsons, Art Lachenbruch, Robert McLaughlin, Robert Coleman, Tetsuzo Seno, Dianne Moore, Barbara Bekins, John Wakabayashi, David Shelly, Art McGarr, and Masaoki Uno. We also thank Art McGarr, David Ponce, and Uri ten Brink for helpful reviews on an earlier draft of this paper. We also thank Roland Bürgmann and Stéphane Guillot for insightful and helpful reviews of the present paper. David Ponce generously provided most of the graphical information shown in Figure 7a,b. Tetsuzo Seno and SHK discussed some of the tectonic implications of our model while the senior author was a JSPS Fellow at the Earthquake Research Institute of the University of Tokyo in 2005 and 2006. Finally, Barbara Bekins provided advice on the hydrological implications of our results. The writers acknowledge funding support from their home institutions, the U.S. Geological Survey and the Geological Survey of Canada. This paper has received the Approval of the Director of the U.S. Geological Survey on 11 June 2014.

\section{Author details}

'U.S. Geological Survey MS 977, 345 Middlefield Road, Menlo Park, CA 94025, USA. ${ }^{2}$ Pacific Geosciences Centre, Geological Survey of Canada, 9860 W. Saanich Rd, Sidney, BC V8L 4B2, Canada.

Received: 14 December 2013 Accepted: 20 May 2014 Published: 7 July 2014

\section{References}

Atwater T (1970) Implications of plate tectonics for the Cenozoic tectonic evolution of western North America. Bull Geol Soc Amer 81:3513-3536 Atwater T, Stock JM (1998) Pacific-North America plate tectonics of the Neogene southwestern United States - an update. Int Geol Rev 40:375-402

Bailey EH, Everhart DL (1964) Geology of the quicksilver deposits of the New Almaden district, Santa Clara County. U.S Geological Survey Professional Paper 360, California, p 206

Barnes I, Hinkel ME, Rapp JB, Heropoulos C, Vaughn WW (1973) Chemical composition of naturally occurring fluids in relation to mercury deposits in part of North-Central California. Geological Survey Bulletin 1382A(I-III):A1-A19

Barnes JD, Eldam R, Lee C-T, Lee A, Errico JC, Loewy S, Cisneros M (2013) Petrogenesis of serpentinites from the Franciscan Complex, western California, USA. Lithos 178:143-157

Becken M, Ritter O, Bedrosian PA, Weckmann U (2011) Correlation between deep fluids, tremor and creep along the central San Andreas fault. Nature Letter 480:87-90

Blakely RJ, Brocher TM, Wells RE (2005) Subduction-zone magnetic anomalies and implications for hydrated forearc mantle. Geology 33:445-448

Bohannon RG, Parsons T (1995) Tectonic implications of the post-30 Ma Pacific and North American relative plate motions. Geol Soc Am Bull 107:937-959

Bostock MG, Hyndman RD, Rondenay S, Peacock SM (2002) An inverted continental Moho and serpentinization of the forearc mantle. Nature 417:536-538

Brocher TM, ten Brink US, Abramovitz T (1999) Synthesis of crustal seismic structure and implications for the concept of a slab gap beneath coastal California. Int Geol Rev 41:263-274

Brocher TM, Parsons T, Tréhu AM, Snelson CM, Fisher MA (2003) Seismic evidence for widespread serpentinized forearc upper mantle along the Cascadia margin. Geology 31:267-270

Christensen NI, Mooney WD (1995) Seismic velocity structure and composition of the continental crust: a global view. J Geophysical Res 100:9761-9788

Coleman RG (1971) Plate tectonic emplacement of upper mantle peridotites along continental edges. J Geophys Res 76:1212-1222

Coleman RG (1977) Ophiolites. Springer Verlag, New York

Coleman RG (1996) New Idria serpentinite: a land management dilemma. Environ Eng Geosci 2:9-22

Coleman RG (2000) Prospecting for Ophiolites along the California Continental Margin. In: Delek Y, Moores EM, Elthon D, Nicolas A (eds) New Insights from Field Studies and the Ocean Drilling Program: Ophiolites and Oceanic Crust. Geological Society of America Special Paper 349, pp 351-364

Deer WA, Howie RA, Zussman J (2009) Rock forming minerals 3B: layered silicates excluding micas and clay minerals, Second edn. Chapter on Serpentine, Secondth edn. The Geological Society, London, pp 157-229

Dickinson WR (1966) Table mountain serpentinite extrusion in California coast ranges. Geol Soc Am Bull 77:451-472

Dickinson WR (1997) Tectonic implications of Cenozoic volcanism in Coastal California. GSA Bull 109:936-954

Dickinson WR, Snyder WS (1979) Geometry of triple junctions related to San Andreas transform. J Geophys Res 84:561-572

Erkan K, Blackwell DD (2008) A thermal test of the post-subduction tectonic evolution along the California transform margin. Geophys Res Lett 35, L07309, doi:10.1029/2008GL033479

Evans BW (2004) The serpentinite multisystem revisited: chrysotile is metastable. Int Geol Rev 46:479-506

Evans BW, Johannes W, Oterdom H, Trommsdorf V (1976) Stability of chrysotile and antigorite in the serpentinite multisystem. Schweiz Mineral Petrogr Mitt 56:79-93

Faulkner DR, Rutter EH (2001) Can the maintenance of overpressured fluids in large strike-slip fault zones explain their apparent weakness? Geology 29:503-506

Fryer P, Ambos EL, Hussong DM (1985) Origin and emplacement of Mariana forearc seamounts. Geology 13:774-777, doi:10.1130/0091-7613(1985) $13<774:$ OAEOMF $>2.0 . \mathrm{CO} ; 2$ 
Fuis GS, Mooney WD (1990) Lithospheric structure and tectonics from seismicrefraction and other data; the San Andreas Fault System, California. In: Wallace RE (ed) The San Andreas Fault System, vol 1515, California: US Geological Survey Professional Paper., pp 207-236

Fulton PM, Saffer DM (2009) Potential role of mantle-derived fluids in weakening the San Andreas Fault. Jof Geophys Res 114:B0708, doi:10.1029/2008JB006087

Furlong KP, Hugo WD, Zandt G (1989) Geometry and evolution of the San Andreas fault zone in northern California. J Geophys Res 94:3100-3110

Godfrey NJ, Neaudoin BC, Klemperer SL (1997) Ophiolitic basement to the Great Valley forearc basin, from seismic and gravity data: implications for crustal growth at the North American continental margin. GSA Bull 108:1536-1562

Gomberg J, Rubinstein JL, Peng Z, Creager KC, Vidale JE (2008) Widespread triggering of non-volcanic tremor in California. Science 319:173, doi:10.1126/ science.1149164

Gutierrez C, Bryant W, Saucedo G, Wills C (2010) Geologic map of California, 2010th edn. California Geological Survey, http://www.conservation.ca.gov/ cgs/cgs_history/Pages/2010_geologicmap.aspx

Hacker BR, Peacock SM, Abers GA, Holloway SD (2003) Subduction factory 2. Are intermediate-depth earthquakes in subducting slabs linked to metamorphic dehydration reactions? J Geophys Res 108:, doi:1029/2001 JB0000

Henstock TJ, Levander A, Hole JA (1997) Deformation in the lower crust of the San Andreas fault system in northern California. Science 278:650-653

Hickman S, Sibson RH, Bruhn R (1995) Introduction to special section; mechanical involvement of fluids in faulting. J Geophysical Res B Solid Earth Planets 100:12,831-12,840

Hilairet N, Reynard B, Wang Y, Daniel I, Merkel S, Nishiyama N, Petitgirard S (2007) High-pressure creep of serpentine, interseismic deformation, and initiation of subduction. Science 318:1910-1913

Hirth G, Guillot S (2013) Rheology and tectonic significance of serpentinite. Elements 9:107-113

Hyndman RD, Peacock SM (2003) Serpentinization of the forearc mantle. Earth Planet Sci Lett 212:417-432

Hyndman RD, Yamano Y, Oleskevich DA (1997) The seismogenic zone of subduction thrust faults. Island Arc 6:2017-2037

Ide S (2010) Striations, duration, migration and tidal response in deep tremor. Nature 466:356-359

Ide S, Shelly DR, Beroza GC (2007) Mechanism of deep low frequency earthquakes: further evidence of deep non-volcanic tremor is generated by shear slip on the plate interface. Geophys Res Lett L03308, doi:10.1029/ 2006gl028890

Ingebritsen SE, Manning CE (2010) Permeability of the continental crust: dynamic variations inferred from seismicity and metamorphism. Geofluids 10:193-205

Irwin WP, Barnes I (1975) Effect of geologic structure and metamorphic fluids on seismic behavior of the San Andreas Fault System in central and northern California. Geology 3:713-716

Irwin WP, Barnes I (1980) Tectonic relations of carbon dioxide discharges and earthquakes. J Geophys Res 85:3115-3121

Jachens RC, Griscom A, Roberts CW (1995) Regional extent of Great Valley basement west of the Great Valley, California; implications for extensive tectonic wedging in the California Coast Ranges. J Geophys Res 100:12769-12,790

Jennings CW, Bryant WA (2010) 2010 Fault Activity Map of California, California Geological Survey Geologic Data Map No. 6., http://www.quake.ca.gov/ gmaps/FAM/faultactivitymap.html

Kennedy BM, Kharaka YK, Evans WC, Ellwood E, DePaolo DJ (1997) Mantle fluids in the San Andreas fault system, California. Science 278:1278-1281

Kharaka YK, Thordsen JJ, Evans WC, Kennedy BM (1999) Geochemistry and hydromechanical interactions of fluids associated with the San Andreas Fault system, California. In: Haneberg WC (ed) Faults and Subsurface Fluid Flow in the Shallow Crust. Geophysical Monograph 113. American Geophysical Union, Washington, D.C, pp 129-148

Kirby SH (1995) Intraslab earthquakes and phase changes in subducting lithosphere - Part of the U.S. Report to the IUGG, Reviews of Geophysics 1995 Supplement. American Geophysical Union, Washington, D.C, pp 287-297

Kirby S, Uno M (2013) Japan Geosciences Union Meeting Abstracts ST06-16. Japan, Chiba, Evidence for multi-stage infiltration of aqueous fluids in a block-emplaced serpentinite along the San Andreas Fault System, Redwood City, California

Kirby S, Uno M (2014) Petrology, Mineralogy \& Geochemistry of the Redwood City Serpentinite with Implications for the Hydrology of the San Andreas
Fault System and the Distributions of Serpentinites in the California Coast Ranges. Program and Abstract Volume, Geofluid 3, O3-12, Tokyo

Kirby SH, Wang K (2002) Intraslab Earthquakes and Processes, and Earthquake Hazards. In: Kirby SH, Wang K, Dunlop S (eds) The Cascadia subduction zone and related subduction systems - seismic structure, intraslab earthquake and processes, and earthquake hazards. US Geological Survey Open File Report 2002-328, 5-8; Geological Survey of Canada Report Open File Report 4350

Kirby SH, Engdahl ER, Denlinger R, Intraslab earthquakes and arc volcanism (1996) Dual physical expressions of crustal and uppermost mantle metamorphism in subducting slabs. In: Bebout G, Scholl D, Kirby S, Platt J (eds) Subduction Top to Bottom. American Geophysical Union, Washington, D.C, pp 195-214, Geophysical Monograph 96

Kirby SH, Wang K, Brocher T (2002) A possible deep, long-term source for water in the northern San Andreas Fault system: a ghost of Cascadia subduction past? Eos Trans AGU 83(47):, AGU Fall Meeting Supplement, Abstract S22B-1038

Kirby SH, Wang K, Brocher T (2003) A possible deep, long-term source for water in the northern San Andreas Fault system: a ghost of subduction past? IUGG Program and Abstracts, SS03/07P/A02-007. Sapporo, Japan

Liu M, Furlong KP (1992) Cenozoic volcanism in the California coast ranges: numerical solutions. J Geophys Res 97(B4):4941-4951

Manning CE, Ingebritsen SE (1999) Permeability of the continental crust: the implications of metamorphic data and hydrothermal systems. Rev Geophys 37:127-150

McCulloch DS (1987) Regional geology and hydrocarbon potential of offshore central California. In: Scholl DW, Grantz A, Vedder JG (eds) Geology and resource potential of the continental margin of western North America and adjacent ocean basins - Beaufort Sea to Baja California, vol 6, Circum-Pacific Council for Energy and Mineral Resources Earth Science Series, Volume. Tulsa, Oklahoma, pp 353-401

Moore JG (2000) Exploring the High Sierra. Stanford University Press, Stanford, California, p 427

Moore DE, Rymer MJ (2007) Talc bearing serpentinite and the creeping section of the San Andreas Fault. Nature 448:795-797, doi: 10.1038/nature06064

Moore DE, Lockner DA, Summers R, Ma S, Byerlee JD (1996) Strength of chrysotile-serpentinite gouge under hydrothermal conditions: can it explain a weak San Andreas fault? Geology 24:1041-1044

Moore DE, Lockner DA, Iwata K, Dhengli M, Summers R, Byerlee JD (1997) Strengths of serpentinite gouges at elevated temperatures. J Geophys Res 102:14787-14801

Moore D, Lockner D, Tanaka H, Iwata KC (2004) Coefficient of friction of Chrysotile gouge at seismogenic depths. Int Geol Rev 46(5):385-398

Murata KJ, Dibblee TW Jr, Drinkwater JL (1979) Thermal effects of large bodies of intrusive serpentinite on overlying Monterey shale, southern Diablo range, Cholame area, California. U.S. Geol Surv Prof Pap 1082:1-8

Murata K, Maekawa H, Yokose H, Yamamoto K, Fujioka K, Ishii T, Chiba H, Wada Y (2009) Significance of serpentinization of wedge mantle peridotites beneath Mariana forearc, western Pacific. Geosphere 5:90-104

Murray J, Langbein J (2006) Slip on the San Andreas Fault at Parkfield, California, over two earthquake cycles, and the implications for seismic hazard. Bull Seismol Soc Am 96:S283-S303, doi:10.1785/0120050820

Murrell SAF, Ismail IAH (1976) The effect of decomposition of hydrous minerals on the mechanical properties of rocks at high pressures and temperatures. Tectonophysics 31:207-258

Nadeau RM, Dolenc D (2005) Nonvolcanic tremors deep beneath the San Andreas fault. Science 307:389

NCEDC (Northern California Earthquake Data Center) (2012). http://www.ncedc.org Accessed January 2012

O'Hanley DS (1996) Serpentinites: records of tectonic and petrologic history. Oxford University Press, UK, Oxford, p 277

Obara K (2002) Nonvolcanic deep tremor associated with subduction in southwest Japan. Science 296:1679-1681

Padrón-Navarta JA, Tommasi A, Garrido CJ, Sanchez-Vizcaino VL, Gomez-Pugnaire MT, Jabalo A, Vauchez A (2010) Fluid transfer into the wedge controlled by high-pressure hydrofracturing in the cold top-slab mantle. Earth Planet Sci Lett 297:271-286

Page BM, de Vito LA, Coleman RG (1999) Tectonic emplacement of serpentinite southest of San Jose, California. Int Geol Rev 41:494-505

Peacock S (1993) Large-scale hydration of the lithosphere above subducting slabs. Chem Geol 108:49-59

Peacock S, Wang K (1999) Seismic consequences of warm versus cool subduction metamorphism: examples from southwest and northeast Japan. Science 286:937-939 
Peng Z, Gomberg J (2010) An integrated perspective of the continuum between earthquakes and slow slip phenomena. Nat Geosci 3:599-607

Peng Z, Vidale JE, Wech AG, Nadeau RM, Creager KC (2009) Remote triggering of tremor along the San Andreas Fault in central California. J Geophys Res 114:B00A06, doi:10.1029/2008JB006049

Ponce DA, Phelps GA, Graymer RW, Jachens RC, Simpson RW, Wentworth CM (2003a) Geophysical anomalies and seismicity suggest a connection between the Hayward and Calaveras Faults, eastern San Francisco Bay Area, Northern California [Abstract]. EOS Trans Am Geophys Union 84: Fall Meeting 2003 Abstract T11D-0425, San Francisco, California

Ponce DA, Hildebrand TG, Jachens RC (2003b) Gravity and magnetic expression of the San Leandro gabbro with implications for the geometry and evolution of the Hayward Fault Zone, Northern California. Bull Seism Soc Am 93:14-26

Ponce DA, Graymer RW, Jachens RC (2008) Segmentation of the Hayward Fault, northern California, inferred from geophysical, geologic, and seismicity data [Abstract]. Seismol Res Lett 79:354. Seismological Society of America 2008 Annual Meeting Abstract, Santa Fe, New Mexico

Raleigh CB, Paterson MS (1965) Experimental deformation of serpentinite and its tectonic implications. J Geophys Res 70:3965-3985

Reynard B (2013) Serpentine in active subduction zones. LITHOS 178:171-185

Rice JR (1992) Fault stress states, pore pressure distributions, and the weakness of the San Andreas fault. In: Evans B, Wong TF (eds) Fault Mechanics and Transport Properties of Rocks. Academic Press Ltd, New York, pp 475-503

Robinson GR Jr, Hass JL Jr, Schafer CM, Haselton HT Jr (1983) Thermodynamic and Thermophysical Properties of Selected Phases in the MgO-SiO ${ }_{2}-\mathrm{H}_{2} \mathrm{O}-\mathrm{CO}_{2}$, $\mathrm{CaO}-\mathrm{Al}_{2} \mathrm{O}_{3}-\mathrm{SiO}_{2}-\mathrm{H}_{2} \mathrm{O}-\mathrm{CO}_{2}$, and Fe-FeO- $\mathrm{Fe}_{2} \mathrm{O}_{3}-\mathrm{SiO}_{2}$ Chemical Systems, With Special Emphasis on the Properties of Basalts and Their Mineral Components. U.S. Geological Survey Open-File Report 83-0079, p 465

Rogers G, Dragert H (2003) Episodic tremor and slip on the cascadia subduction zone: the chatter of silent slip. Science 300:1942-1943

Rytuba JJ (1986) Descriptive Model of Silica-Carbonate Hg. In: Cox DP, Singer DA (eds) Mineral Deposit Models. U.S. Geological Survey Bulletin 1693, USA, p 181

Sass J, Wiliams CF, Lachenbruch AH, Galanis SP, Grubb FV (1997) Thermal regime of the San Andreas fault near Parkfield. J Geophys Res 102:27,575-27,585

Saumur B-M, Hattori K, Guillot S (2010) Serpentinized abyssal and forearc peridotites in northern Dominican Republic: HP-LT mélange formation and protrusion along major strike-slip faults in an oceanic subduction complex. Geol Soc Am Bull 122:292-304, doi:10.1130/B26530.1

Schleicher AM, van der Pluijm BA, Warr LN (2006) Origin and significance of claycoated fractures in mudrock fragments of the SAFOD borehole (Parkfield, California). Geophys Res Lett 33, L16313, doi:10.1029/2006GL026505

Schleicher AM, van der Pluijm BA, Warr LN (2010) Nanocoatings of clay and creep of the San Andreas fault at Parkfield, California. Geology 38:667-670, doi:10.1130/G31091.1

Schwartz S, Guillot S, Reynard B, Lafay R, Nicollet C, Debret B, Auzende AL (2013) Pressure-temperature estimates of the lizardite/antigorite transition in high pressure serpentinites. Lithos 178:197-210, doi.org/10.1016/.lithos.2012.11.023

Seno T, Kirby SH (2014) Formation of plate boundaries: the role of mantle volatilization. Earth Sci Rev 129:85-99

Shelly DR, Hardebeck JL (2010) Precise tremor source locations and amplitude variations along the lower-crustal central San Andreas Fault. Geophys Res Lett 37, L14301, doi:10.1029/2010GL043672

Sibson RH (1996) Structural permeability of fluid-driven fault-fracture meshes. J Struct Geol 18:1031-1042

Sibson RH (2002) Geology of the crustal earthquake source. In: Lee WHK, Jennings P, Kisslinger C, Kanamori H (eds) International Handbook of Earthquake \& Engineering Seismology, vol 1, Part., pp 455-489

Sleep NH, Blanpied M (1992) Creep, compaction, and the weak rheology of major faults. Nature 359:687-692

ten Brink US, Dhimizu N, Mozer PC (1999) Plate deformation at depth under northern California: slab gap or stretched slab? Tectonics 18:1084-1098

Thomas AM, Nadeau RM, Bürgmann R (2009) Tremor-tide correlations and nearlithostatic pore pressure on the deep San Andreas fault. Nature 462:, doi:10.1038/nature08654

Ulmer P, Trommsdorf V (1995) Serpentine stability to mantle depths and subduction-related magmatism. Science 268:858-861

USGS (2014) Quaternary fault and fold database. http://earthquake.usgs.gov/ hazards/qfaults/citation.php. Accessed 24 February 2014

Wada I, Wang K (2009) Common depth of slab-mantle decoupling: reconciling diversity and uniformity of subduction zones. Geochem Geophys Geosyst 10(10), Q10009, doi:10.1029/2009GC002570
Wada I, Wang K, He J, Hyndman R (2008) Weakening of the subduction interface and its effects on surface heat flow, slab dehydration, and mantle wedge serpentinization. J Geophys Res 113, B04402, doi:10.1029/2007JB005190

Wakabayashi J (2004) Contrasting settings of serpentinite bodies, San Francisco Bay area, California: derivation from the subducting plate vs. Mantle hanging wall. Int Geol Rev 46:1103-1118

Wakabayashi J (2005) Franciscan Complex and Coast Range Ophiolite, eastern margin of San Francisco Bay, California: Major components of the former convergent plate boundary. In: Stevens C, Cooper J (eds) Mesozoic tectonic assembly of California Pacific Section, vol 96, Society for Sedimentary Geology Pacific Section (SEPM) Book. Tulsa, Oklahoma, pp 1-20

Wakabayashi J (2011) Mélanges of the Franciscan Complex, California: Diverse structural settings, evidence for sedimentary mixing, and their connection to subduction processes. In: Wakabayashi J, Dilek Y (eds) Mélanges: Processes of Formation and Societal Significance, Geological Society of America Special Paper 480., pp 117-141, doi:10.1130/2011.2480(05)

Wakabayashi J (2012) Subducted sedimentary serpentinite mélanges: record of multiple burial-exhumation cycles and subduction erosion. Tectonophysics 568-569:230-247

Wakabayashi J, Dilek Y (2011) Introduction: characteristics and tectonic settings of mélanges, and their significance for societal and engineering problems. In: Wakabayashi J, Dilek Y (eds) Mélanges: processes of formation and societal significance., Geol Soc Am Spec Pap 480:5-10, doi:10.1130/2011. 2480(00)

Wakabayashi J, Ghatak A, Basu AR (2010) Tectonic setting of supra subduction zone ophiolite generation and subduction initiation as revealed through geochemistry and regional field relationships. Geol Soc Am Bull 122:1548-1568, doi:10.1130/B30017.1

Waldhauser F, Schaff DP (2008) Large-scale relocation of two decades of Northern California seismicity using cross-correlation and double-difference methods. J Geophys Res 113, B08311, doi:10.1029/2007JB005479

Wallace RF (1990) Chapter 1. General Features. The San Andreas Fault System, California. USGS Prof Paper 1515:3-12

Wang K, Mulder T, Rogers GC, Hyndman RD (1995) Case for low coupling stress on the Cascadia subduction fault. J Geophys Res 100:12,907-12,918

Zandt G, Furlong KP (1982) Evolution and thickness of the lithosphere beneath coastal California. Geology 10:376-381

Zoback MD, Zoback ML, Mount VS, Suppe J, Eaton JP, Healy JH, Oppenheimer D, Reasenberg P, Jones L, Raleigh CB, Wong IG, Scott O, Wentworth C (1987) New evidence on the state of stress of the San Andreas fault system. Sci New Series 238:1105-1111

Zoback MD, Zoback ML, Mount VS, Suppe J, Eaton JP, Healy JH, Oppenheimer D, Reasenberg P, Jones L, Raleigh CB, Wong IG, Scott O, Zoback MD, Beroza GC (1993) Evidence for a nearly frictionless faulting in the 1989 (M6.9) Loma Prieta, California, earthquake and its aftershocks. Geology 21:181-185

Zoback M, Hickman S, Ellsworth W, the SAFOD Science Team (2011) Scientific drilling into the San Andreas fault zone - an overview of SAFOD's first five years. Sci Drill 11:1-28, doi:10.2204/iodp.sd.11.02.2011

doi:10.1186/1880-5981-66-67

Cite this article as: Kirby et al:: A large mantle water source for the northern San Andreas fault system: a ghost of subduction past. Earth, Planets and Space 2014 66:67.

\section{Submit your manuscript to a SpringerOpen ${ }^{\odot}$ journal and benefit from:}

- Convenient online submission

$\checkmark$ Rigorous peer review

- Immediate publication on acceptance

- Open access: articles freely available online

- High visibility within the field

- Retaining the copyright to your article

Submit your next manuscript at $>$ springeropen.com 